\title{
NEK11 as a candidate high-penetrance melanoma susceptibility gene
}

\author{
Eirini Christodoulou (D) , ${ }^{1}$ Remco van Doorn, ${ }^{1}$ Mijke Visser, ${ }^{1}$ Amina Teunisse, ${ }^{2}$ \\ Mieke Versluis, ${ }^{3}$ Pieter van der Velden, ${ }^{3}$ Nicholas $\mathrm{K}$ Hayward, ${ }^{4}$ Aart Jochemsen, ${ }^{2}$ \\ Nelleke Gruis ${ }^{1}$
}

\begin{abstract}
- Additional material is
published online only. To view please visit the journal online (http://dx.doi.org/10.1136/ jmedgenet-2019-106134).
\end{abstract}

${ }^{1}$ Dermatology, Leids Universitair Medisch Centrum, Leiden, ZuidHolland, The Netherlands ${ }^{2}$ Cell and Chemical Biology, Leids Universitair Medisch Centrum, Leiden, Zuid-Holland, The Netherlands ${ }^{3}$ Ophthalmology, Leids Universitair Medisch Centrum, Leiden, Zuid-Holland, The Netherlands

${ }^{4}$ Cancer Program, QIMR Berghofer Medical Research Institute, Brisbane, Queensland, Australia

\section{Correspondence to} Dr Eirini Christodoulou, Leiden University Medical Center (LUMC), Albinusdreef 22333 ZA Leiden, The Netherlands; e.christodoulou@lumc.nl

$A J$ and $N G$ are joint senior authors.

Received 6 March 2019

Accepted 10 October 2019 Published Online First 8 November 2019

\section{ABSTRACT}

Background A proportion of patients diagnosed with cutaneous melanoma reports a positive family history. Inherited variants in CDKN2A and several other genes have been shown to predispose to melanoma; however, the genetic basis of familial melanoma remains unknown in most cases. The objective of this study was to provide insight into the genetic basis of familial melanoma.

Methods In order to identify novel melanoma susceptibility genes, whole exome sequencing (WES) analysis was applied in a Dutch family with melanoma. The causality of a candidate variant was characterised by performing cosegregation analysis in five affected family members using patient-derived tissues and digital droplet PCR analysis to accurately quantify mutant allele frequency. Functional in-vitro studies were performed to assess the pathogenicity of the candidate variant.

Results Application of WES identified a rare, nonsense variant in the NEK11 gene (c.1120C>T, p.Arg374Ter), cosegregating in all five affected members of a Dutch family. NEK11 (NIMA-related Kinase 11) is involved in the DNA damage response, enforcing the G2/M cell cycle checkpoint. In a melanoma from a variant carrier, somatic loss of the wildtype allele of this putative tumour suppressor gene was demonstrated. Functional analyses showed that the NEK11 p.Arg374Ter mutation results in strongly reduced expression of the truncated protein caused by proteasomal degradation.

Conclusion The NEK11 p.Arg374Ter variant identified in this family leads to loss-of-function through protein instability. Collectively, these findings support NEK11 as a melanoma susceptibility gene.

\section{INTRODUCTION}

Cutaneous melanoma is an aggressive type of skin cancer resulting from malignant transformation of melanocytes. Incidences of melanoma continue to rise steadily, with more than 230000 cases diagnosed each year worldwide, accompanied by 55000 deaths. ${ }^{1}$ Ten per cent of cases are found in people with familial predisposition, that is, families with at least two first degree relatives with melanoma. ${ }^{2}$

Several high-penetrance melanoma susceptibility genes have been identified and account for approximately $40 \%$ of melanoma families. ${ }^{34}$ The majority of these families are affected by germline mutations in $C D K N 2 A^{5}$, a key cell-cycle checkpoint regulator and first reported high-penetrance melanoma susceptibility gene. ${ }^{6-8}$ Following CDKN2A, germline mutations in other genes have been linked to familial predisposition to melanoma; these include $C D K 4^{9}$ and $B A P 1 .^{10} 11$ Biallelic inactivation has been reported in tumour tissues with germline variants in BAP1 including mesothelioma, uveal melanoma and cutaneous melanoma ${ }^{12}{ }^{13}$ suggesting that genetic analysis is an informative approach for discovering melanoma-predisposition genes. Considering the discovery of germline MITF variants ${ }^{14} 15$ suggesting that genetic analysis in patient's tissues and functional validation adds to the current value of mutation screening. Application of whole exome sequencing (WES) analysis has been successful in identifying rare variants including TERT promoter, ${ }^{16}$ POT $1,{ }^{17}$ TERF $2 I P$ and $A C D,{ }^{18}$ GOLM1, ${ }^{19} \mathrm{EBF3}^{20}$ and $P O L E^{21}$ as candidate highpenetrance melanoma susceptibility genes. Still, the genetic basis of over half of melanoma families remains unknown, impairing genetic testing and counselling in families with predisposition to melanoma. ${ }^{22} 23$ Here, NEK11 gene was identified by WES in a Dutch family with melanoma and characterised as a potential novel high-penetrance melanoma-susceptibility gene.

\section{METHODS}

Whole exome sequencing (WES)

Study population and ethics approval

WES was carried out in blood-derived DNA samples of two members of a Dutch familial melanoma family. Study approval was obtained by the ethics committee of Leiden University Medical Center (LUMC, P00.117).

\section{Sequencing analysis and bioinformatics}

Sequencing was performed on Hiseq2000 platform with TruSeq Exome Enrichment kit. Paired-end reads of $110 \mathrm{bp}$ were generated with mean coverage of $40 \times$. The Burrows-Wheeler aligner was used for mapping sequencing reads to the reference UCSC human genome. Single nucleotide variants (SNVs) were detected using samtools/bcftools. Indels were detected with Pindel and annotated to dbSNP144 using ANNOVAR. Variants altering the coding sequence were selected excluding those that were present at a frequency of $0.0005 \%$ or higher in the Kaviar (Known VARiants) control population database, including 162 million variants from human genomes of datasets such as ExAc and $1000 \mathrm{Gs}^{24}$ 
Selection, validation and interpretation of variants

Variants identified were assessed to identify pathogenic or potentially pathogenic variants in ClinVar. Variants were then filtered using in-silico prediction algorithms to show if an alteration affects protein function. Details about criteria for interpretation of variants has been reported previously. ${ }^{25}$ These included exonic, frameshift, non-synonymous SNVs, splicing and stopgain SNVs. We then focused on segregating mutations between all family members and functional significance. Cosegregation of NEK11 p.Arg374Ter mutation was confirmed using Sanger sequencing of germline DNA from family members 1, 4, 5, 7 and 12 (online supplementary table S1) (Macrogen, Amsterdam, The Netherlands).

\section{Genotyping and LOH analysis}

DNA was extracted from primary melanoma FFPE tissue of a NEK11 p.Arg374Ter mutation carrier (family member 5) using the QIAamp DNA formalin-fixed paraffin-embedded (FFPE) Tissue kit (QIAGEN, Venlo, The Netherlands) according to manufacturer's instructions. DNA extraction of normal and tumour tissue was obtained through microdissection/punch biopsy by the pathology department of LUMC, The Netherlands. Genomic primer sets were used to amplify the region of interest containing the mutation (NEK11 c.1120C > T) and a common SNP (rs4974475, chr3:130882827, minor allele frequency (MAF) 17\%), located at $2 \mathrm{~kb}$ upstream from the NEK11 mutation site to verify Loss of Heterozygosity (LOH) (online supplementary table S1). PCR products were cleaned-up using a PCR clean-up protocol (Bio-Rad, Hercules, California, USA) and sequenced by Sanger sequencing analysis-long run (Macrogen, Amsterdam, The Netherlands). Chromatograms were then analysed by Chromas Technelysium DNA Sequencing Software (Technelysium Pty Ltd, South Brisbane, Australia).

\section{Droplet digital PCR (ddPCR)}

Mutation detection assays specific for ddPCR (Bio-Rad, Hercules, California, USA) describe the incorporation of both wild-type and mutated targets in a single ddPCR mix. In this case, the assay was designed for the detection of NEK11 p.Arg374Ter mutation. Detailed protocol of mutation detection ddPCR assay has been described previously ${ }^{26}$ and ddPCR sequence information is provided in online supplementary table S1. QuantaSoft software (Bio-Rad, Hercules, California, USA) was used to analyse the data by calculating the concentration of the amplified ddPCR product (copies/ $/$ l). ${ }^{26}$ The wild-type (WT) allele frequency was calculated by dividing the WT allele counts over the total allele counts and the mutant (MT) allele frequency was calculated by dividing MT allele counts over the total allele counts.

\section{Cell culturing and maintenance}

U2OS (human osteosarcoma tumour cell line) and FM6 (human cutaneous malignant melanoma cell line) cells were maintained in DMEM medium supplemented with penicillin (100 I.U./mL)/ streptomycin $(100 \mu \mathrm{g} / \mathrm{mL})$ and $10 \%$ Fetal bovine serum (FBS) and glutamax $100 \times$ (Thermo Fisher Scientific, Waltham, Massachusetts, USA). All cells were grown in a humidified incubator at $37^{\circ} \mathrm{C}$ and $5 \% \mathrm{CO}_{2}$ and routinely subcultured when reaching $95 \%$ confluency.

\section{Plasmid construction and introduction of NEK11 p.Arg374Ter mutation}

NEK11-FL (full-length isoform ${ }^{27}$ ) was expressed from a plasmid construct containing WT NEK11 cDNA, fused with N-terminal
FLAG-epitope tag (Kind gift from professor Andrew Fry, University of Leicester, UK) for expression in U2OS and FM6 cells. ${ }^{27}$ Site-directed mutagenesis was applied to introduce NEK11 p.Arg374Ter mutation in flag-tagged NEK11 expression vectors. Primer-sets were designed specifically targeting the mutation site of NEK11 exonic sequence (online supplementary table S1). Thermal cycling was performed to introduce the mutation consisting of $1 \mathrm{~min}$ denaturation at $95^{\circ} \mathrm{C}$, followed by 10 cycles of $1 \mathrm{~min}$ steps at $95^{\circ} \mathrm{C}, 63^{\circ} \mathrm{C}$ and $68^{\circ} \mathrm{C}$. The PCR product was then digested with DpnI enzyme and transformed into Top10 bacteria to produce inducible vectors for functional experiments. Sequences of both NEK11 WT and MT expression vectors were confirmed by Sanger Sequencing analysis long-run (Macrogen, Amsterdam, The Netherlands) (online supplementary table S1).

\section{Lentivirus production}

NEK11 WT and MT cDNAs were recloned into a lentiviral backbone containing the neomycin resistance gene. Lentiviral stocks were produced by transfections into HEK-293T cells as described previously ${ }^{28}$ but calcium phosphate was replaced with polyethylenimine (PEI) in the transfection mix. Virus was quantified by antigen capture ELISA measuring HIV p24 levels (ZeptoMetrix, New York, New York, USA).

\section{Transient transfections}

U2OS cells were harvested and seeded in appropriate growth medium in 6 -well plates $\left(0.5 \times 10^{5}\right.$ cells $\left./ \mathrm{mL}\right)$ and $60 \mathrm{~mm}$ dishes $\left(1.8 \times 10^{5}\right.$ cells $\left./ \mathrm{mL}\right)$. The DNA mix was prepared as follows: $0.8 \mu \mathrm{g} \quad$ pLV-NEO-NEK11-WT, $\quad$ LLV-NEO-NEK11-MT and $p L V$-NEO-empty lentiviral vectors (see lentivirus production section), $0.1 \mu \mathrm{g}$ Tomato-Red, $300 \mathrm{ng}$ of GFP expression vector and $0.2 \mu \mathrm{g}$ pSuper. The PEI mix was prepared as follows: $3: 1 \mathrm{PEI}$ (3 parts of PEI to 1 part of DNA concentration) diluted in Gibco Opti-MEM Reduced Serum medium (Thermo Fisher Scientific, Waltham, Massachusetts, USA). PEI mix was added slowly to DNA mix followed by a short vortex. The mixture was kept at RT for $20 \mathrm{~min}$ and then added dropwise to U2OS cells. Growth medium was replaced 16 hours after transfection and U2OS cells were further incubated for another 24 hours.

\section{Lentiviral transductions}

Fresh culture media were prepared with viral supernatants supplemented with $8 \mu \mathrm{g} / \mathrm{mL}$ polybrene (Sigma-Aldrich, St. Louis, Missouri, USA). FM6 cells were seeded in 6-well plates at a density of $2 \times 10^{5}$ cells/well. FM6 cells were incubated with virus-containing medium overnight, after which the cells were refed with fresh medium containing G418 (Sigma-Aldrich, St. Louis, Missouri, USA) to produce stable cell lines expressing NEK11 WT and MT by using neomycin as selection marker.

\section{RNA isolation, CDNA synthesis and gene expression analysis} Lymphocytic RNA of a NEK11 p.Arg374Ter carrier (family member 18) and a non-relative spouse was isolated using the RNeasy micro kit from QIAGEN (Venlo, The Netherlands). RNA was isolated from FM6 cells using the SV total RNA isolation kit (Promega, Fitchburg, Wisconsin, USA). First strand cDNA synthesis was carried out using the iScript c-DNA synthesis kit (Bio-Rad, Hercules, California, USA) and Sanger Sequencing analysis (LGTC, LUMC, The Netherlands) was used to detect presence of NEK11 WT and MT alleles (Primer sequences shown in online supplementary table S1). NEK11 gene expression was confirmed using SYBR green based quantitative PCR on CFX384 Touch Real-Time PCR Detection System (Bio-Rad, 


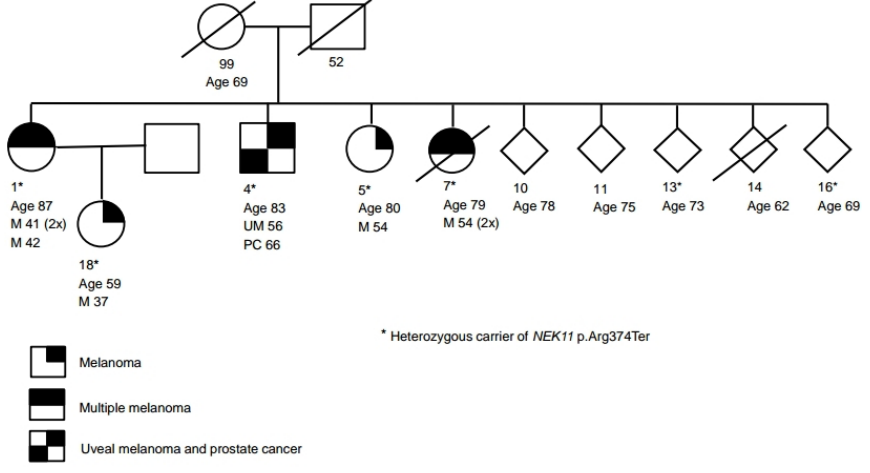

Figure 1 Cosegregation of NEK11 p.Arg374Ter in a Dutch melanoma family. Whole-exome sequencing was carried out for family members 1 and 4. Cosegregation of NEK11 p.Arg374Ter was confirmed by analysing germline DNA from all family members. Current age and age at death of deceased individuals (those reported) are indicated. Age at diagnosis of each tumour type is noted in affected family members. $\mathrm{M}$, melanoma; $\mathrm{PC}$ prostate cancer; UM, uveal melanoma.

Hercules, California, USA) (online supplementary table S1). Gene expression results were analysed using Bio-Rad CFX Manager 3.1 Software (Hercules, California, USA) and corrected relative to reference gene expression (CAPNS1 and SRPR) as well as transfection efficiency target Tomato-Red (online supplementary table S1).

\section{Immunofluorescence staining}

Transfected U2OS cells on cover slips were washed twice in phosphate-buffered saline (PBS) solution and fixed with 4\% paraformaldehyde for $10 \mathrm{~min}$. Cover slips with U2OS cells were then incubated for $10 \mathrm{~min}$ in PBS/0.2\%Triton-X100 (permeabilisation) and preincubated for $30 \mathrm{~min}$ in PBS/0.05\% Tween-20 containing 5\% normal goat serum (NGS). Subsequently, U2OS cells were incubated with monoclonal anti-flag M2 Catalog Number F1804 (Sigma-Aldrich, St. Louis, Missouri, USA) diluted in PBS/Tween/NGS (1:500) for $60 \mathrm{~min}$ at room temperature followed by washing three times in PBS/Tween for a total of $15 \mathrm{~min}$. The secondary antibody, anti-Mouse IgG-Cy2 (\#115225-146, Jackson ImmunoResearch Laboratories, Cambridge, UK) was diluted in PBS/Tween/NGS (1:100) and added at room temperature in the dark. U2OS cells were finally washed for 10 min with PBS/Tween and coverslips were placed on slides for analysis on a Leica DMRA fluorescent microscope (Nijmegen, The Netherlands).

\section{Drug treatments}

MG132 proteasome inhibitor (Sigma-Aldrich, St. Louis, Missouri, USA) was added to U2OS and FM6 cells at a final concentration of $20 \mu \mathrm{M}$ for 5-6 hours before RNA and protein isolation procedures. The cycloheximide (CHX), translation inhibitor, was added at a concentration of $50 \mu \mathrm{g} / \mathrm{mL}$ (SigmaAldrich, St. Louis, Missouri, USA) to FM6 stable-cell lines expressing NEK11 WT and NEK11 MT as a time-course treatment of $0,1,2$ and 4 hours.

\section{Protein isolation and Western immunoblotting analysis}

U2OS and FM6 cells were washed twice in ice-cold PBS and incubated on ice for $10 \mathrm{~min}$ in Giordano buffer $(50 \mathrm{mM}$ Tris- $\mathrm{HCl}$ pH7.4, $250 \mathrm{mM} \mathrm{NaCl}, 0.1 \%$ Triton X-100 and $5 \mathrm{mM}$ EDTA; supplemented with phosphatase and protease inhibitors). Lysates were collected by scraping and centrifuged at max speed for $10 \mathrm{~min}$ and protein concentration was determined using the Bradford method. Western Blot procedure was followed as described previously. ${ }^{29}$ NEK11 protein was detected by the Anti-Flag antibody (1:1000) (Sigma-Aldrich, St. Louis, Missouri, USA) and the controls were detected by Anti-USP7 (1:1000) (Bethyl Laboratories, Biomol, Montgomery, Texas, USA), AntiGAPDH (1:1000) (Sigma-Aldrich, St. Louis, Missouri, USA) and Anti-P53 (1:1000) (Santa Cruz Biotechnology, Heidelberg, Germany). After transient expression, protein levels were determined using the Odyssey machine (LI-COR, Lincoln, Nebraska, USA) and analysed using Odyssey software according to manufacturer's instructions. Secondary antibodies used were IRDye 800CW Goat anti-Mouse $\operatorname{IgG}(\mathrm{H}+\mathrm{L}), 0.1 \mathrm{mg}(1: 5000)$ and IRDye 680LT Goat anti-Rabbit IgG $(\mathrm{H}+\mathrm{L}), 0.1 \mathrm{mg}(1: 5000)$ (LICOR, Lincoln, Nebraska, USA). Due to low protein expression in stably-transduced FM6 cells, the ChemiDoc Imaging System was used to detect proteins with increased sensitivity and specificity. The bands were analysed with Image lab software (BioRad, Hercules, California, USA) according to manufacturer's instructions. Protein-expression quantification was performed relative to unaffected expression of controls (GAPDH, USP7).

\section{Statistical analysis}

All data were analysed by calculating the mean and SD and graphs were obtained in GraphPad Prism V.7 (GraphPad software, San Diego, California, USA). Analysis of variance and multiple comparisons were applied to detect statistically significant differences between expression patterns of three independent experiments $(n=3)$. Statistical significance was reached when $\mathrm{p}<0.05$.

\section{RESULTS}

\section{WES analysis and identification of NEK11 p.Arg374Ter}

A Dutch melanoma family presented four melanoma cases and one uveal melanoma case with prostate cancer. The diagnosis of melanoma in five members in multiple generations strongly suggests an autosomal-dominant mode of inheritance (figure 1) and members were negative for mutations in established melanoma susceptibility genes (CDKN2A, BAP1, POT1, TERT, TERF2IP, ACD, MITF, GOLM1, EBF3). A WES analysis was carried out on DNA from blood cells of two affected members (figure 1). Among a total of 19 rare, cosegregating nonsynonymous variants that met our criteria, 17 were missense mutations, probably damaging, predicted deleterious. ${ }^{3031}$ These variants, however, are not plausible candidate melanoma susceptibility genes (table 1) since there is no evidence supporting a strong tumorigenic effect based on published literature. Interestingly, two were nonsense stop-gain SNVs (table 1). One candidate stop-gain variant was p.Arg66Ter in ZNF192, a gene possibly regulating transcription. However, no implications in cancer have been mentioned in published literature. In contrast, the other candidate was a truncating variant (p.Arg374Ter) in the never in mitosis-gene A (NIMA)-related kinase 11 (NEK11). This family of proteins functions in different aspects of cell cycle regulation, although the in-depth role of NIMA-related kinases remains to be uncovered. ${ }^{32}$ NEK11 has been reported to be somatically mutated in different types of cancer, including lung, breast, prostate and melanoma. ${ }^{33}$ The frequency of NEK11 mutations was $>5 \%$ in melanomas ${ }^{34}$ suggesting a plausible candidate in melanoma development.

Sanger sequencing confirmed NEK11 p.Arg374Ter to cosegregate within four cutaneous melanoma cases and one uveal melanoma case in this Dutch melanoma family (figure 1). Family 


\begin{tabular}{|c|c|c|c|c|c|c|c|c|}
\hline Gene & Change & $\mathrm{Ch}$ & Ref & Alt & Type* & SIFT & Polyphen & MAFt \\
\hline GPATCH3 & p.Gly131Arg & 1 & C & $\mathrm{T}$ & Missense & Deleterious & probably_damaging & 0.00006168 \\
\hline ATPIF1 & p.Arg94His & 1 & G & A & Missense & Deleterious & probably_damaging & 0.00004406 \\
\hline KALRN & p.Ser1629Cys & 3 & C & G & Missense & Deleterious & probably_damaging & 0.00002641 \\
\hline NEK11 & p.Arg374Ter & 3 & $\mathrm{C}$ & $\mathrm{T}$ & Stop-gained & & & 0.00002641 \\
\hline ZNF192 & p.Arg66Ter & 6 & $\mathrm{C}$ & $\mathrm{T}$ & Stop-gained & & & 0.000008791 \\
\hline GPR111 & p.Ser168Arg & 6 & $\mathrm{~T}$ & A & Missense & Deleterious & probably_damaging & 0.00006486 \\
\hline GPAM & p.Pro403Thr & 10 & G & $\mathrm{T}$ & Missense & Deleterious & probably_damaging & 0.000008794 \\
\hline NELL1 & p.Val755Met & 11 & G & A & Missense & Deleterious & probably_damaging & 0.0002261 \\
\hline KRT77 & p.Asp316Asn & 12 & C & $\mathrm{T}$ & Missense & Deleterious & probably_damaging & 0.00001502 \\
\hline OAS2 & p.Tyr269Cys & 12 & A & G & Missense & Deleterious & probably_damaging & - \\
\hline DNAJC3 & p.Arg346Gln & 13 & G & A & Missense & Deleterious & probably_damaging & 0.0001553 \\
\hline TEP1 & p.Arg1386Trp & 14 & G & A & Missense & Deleterious & possibly_damaging & 0.001266 \\
\hline PLCB2 & p.Arg253Trp & 15 & G & A & Missense & Deleterious & probably_damaging & 0.001074 \\
\hline DNASE1 & p.Ala168Val & 16 & $\mathrm{C}$ & $\mathrm{T}$ & Missense & Deleterious & possibly_damaging & 0.001402 \\
\hline BFAR & p.Phe53lle & 16 & $\mathrm{~T}$ & A & Missense & Deleterious & possibly_damaging & - \\
\hline ITGB4 & p.Arg556Cys & 17 & $\mathrm{C}$ & $\mathrm{T}$ & Missense & Deleterious & possibly_damaging & 0.0006357 \\
\hline PSG7 & p.Trp67Ser & 19 & C & G & Missense & Deleterious & probably_damaging & 0.0001473 \\
\hline GPR50 & p.Gly93Ala & $\mathrm{X}$ & G & C & Missense & Deleterious & possibly_damaging & 0.00001240 \\
\hline GABRQ & p.Arg254Cys & $\mathrm{x}$ & C & $\mathrm{T}$ & Missense & Deleterious & probably_damaging & 0.00007713 \\
\hline
\end{tabular}

*Variants characterised by ExAC/gnomAD/Genome of The Netherlands/Ensembl databases.

TMAF in European (Non-Finnish) population.

WES, whole-exome sequencing.

members 13 and 16 were also found to be NEK11 p.Arg374Ter carriers although with no clinical presentation of cancer/melanoma. Considering the current age of these individuals and absence of the melanoma phenotype, the possibility for nonpenetrance is very likely (figure 1). Somatic loss of the wildtype (WT) allele was detected in primary cutaneous melanoma tissue of a mutation carrier (figure $2 \mathrm{~A}-\mathrm{C}$ ) and confirmed by the highly sensitive and quantitative method, droplet digital PCR (ddPCR) ${ }^{36}$ whereby, a higher fraction of NEK11 p.Arg374Ter mutant (MT) than NEK11 WT allele was detected in melanoma tissue when compared with normal tissue micro dissected from the same biopsy sample (figure 2D). Furthermore, examination of a common SNP (rs4974475, chr3:130882827, MAF 17\%), showed loss of this variant in the melanoma tissue of a NEK11 p.Arg374Ter carrier, suggesting LOH over a longer genetic region (online supplementary figure S1). Collectively, these data suggest a potential loss-of-function (LOF) mutagenic effect of NEK11 p.Arg374Ter.

\section{Functional analysis of NEK11 p.Arg374Ter}

Following genetic characterisation of NEK11 p.Arg374Ter as a potential LOF mutation, functional analyses were performed to investigate the effects of this truncating mutation on the expression level of NEK11 mRNA and NEK11 protein. On transient transfection of NEK11 expressing plasmids in osteosarcoma tumour cell line U2OS, the expression of NEK11 MT mRNA was lower than NEK11 WT mRNA, although the difference was statistically not significant (online supplementary figure S2). U2OS cell-line provided the ideal conditions for functional analysis since it is an easily transfectable, fast-growing cell line and has been previously used to functionally characterise NEK11. ${ }^{27} 3738$ NEK11 MT mRNA expression was detected in lymphocyte mRNA of a mutation carrier by Sanger sequencing and ddPCR analyses (figure $3 \mathrm{~A}-\mathrm{C}$ ) suggesting that the premature stop codon does not result in significant transcript degradation by nonsense-mediated mRNA decay (NMD). Combined with the finding that the mutant NEK11 mRNA was detected in U2OS cells (online supplementary figure S2), these results indicate no significant effect of the mutation on NEK11 mRNA expression levels.

Introduction of p.Arg374Ter mutation in the NEK11 expression vector, resulted in synthesis of a truncated NEK11 protein lacking the whole C-terminal PEST-like domain as well as part of the coiled-coil motifs (online supplementary figure S3a). The coiled-coil region regulates protein activation suggesting that loss or absence of these motifs would affect protein function. ${ }^{39}$ The truncated protein runs at approximately $45 \mathrm{kDa}$, which reasonably fits with the size of 373 amino acids (online supplementary figure S3a). Immunoblot analysis of protein lysates made from transfected U2OS cells showed that the level of the truncated protein was threefold lower than NEK11 WT expression $(\mathrm{p}<0.005$; figure 4A, B) when corrected for mRNA expression. Treatment with the proteasome inhibitor MG132 increased NEK11 protein level, particularly of the truncated product $(\sim 2$-fold). Still, the difference between NEK11 WT and MT protein levels in lysates of MG132-treated U2OS cells is significant $(\mathrm{p}<0.005)$. Collectively, statistically significant lower protein expression was correlated with the NEK11 p.Arg374Ter mutation.

Since a distinct subcellular localisation of NEK11-FL (645 amino acids) and NEK11-S (450 amino acids) has been reported, ${ }^{27}$ which might affect the protein expression level, the subcellular localisation of the Flag-tagged NEK11 MT was investigated in comparison to Flag-tagged NEK11-FL. Interestingly, both proteins were mainly localised in the nucleus of U2OS cells (online supplementary figure S3b), in contrast to the earlier publication. However, in that publication GFP-tagged constructs were used. Indeed, using the same GFP-tagged constructs the subcellular localisation of NEK11-FL and NEK11-S was as reported; the GFP-NEK11 MT protein localised in the nucleus, similar to GFP-NEK11-S (data not shown).

Since transient overexpression yields very high expression levels which might partly mask normal regulation of NEK11 protein expression, a putative difference in protein expression of the NEK11 WT and the NEK11 MT was studied in more 
A

Germline DNA

(Family member 14)

B

Germline DNA (Family member 5)

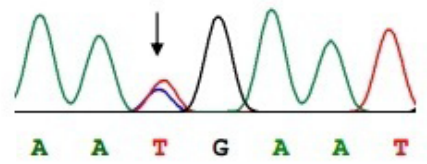

C

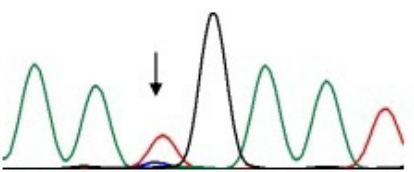

D

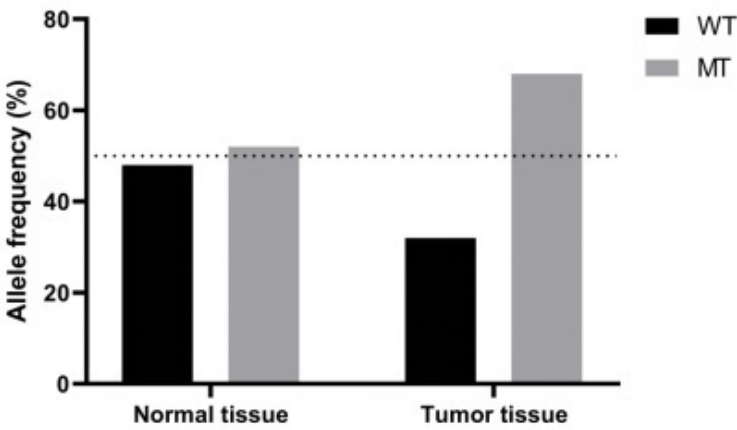

Figure $2 \mathrm{LOH}$ analysis of a NEK11 p.Arg374Ter mutation carrier. Chromatogram showing DNA sequence of (A) healthy family member (14), (B) a NEK11 p.Arg374Ter carrier (family member 5) and (C) tumour of a NEK11 p.Arg374Ter carrier (family member 5). Arrows indicate the NEK11 p.Arg374Ter mutation site. (D) ddPCR NEK11 mutation assay showing the NEK11 (WT) and NEK11 p.Arg374Ter (MT) allele frequency detected in normal and tumour tissue from FFPE derived DNA of family member 5. WT, wildtype.

detail in stably-transduced, disease-relevant FM6 cutaneous melanoma cells. Strikingly, NEK11 MT protein expression was hardly detectable with sixfold difference compared with NEK11 WT when corrected to mRNA levels $(p=0.0024)$ (figure $5 A, B)$. Furthermore, treating FM6 cells with MG132 strongly increased NEK11 MT protein level (figure 5C), while the effect of MG132 on NEK11 WT levels was much less pronounced, suggesting that the truncated NEK11 protein is prone to faster protein degradation. To examine protein half-life of the NEK11 WT and MT proteins, we decided to treat these FM6 cells with the protein translation inhibitor $\mathrm{CHX}$ and harvest at different time-points. The NEK11 WT protein appeared to be a stably expressed protein with half-life of approximately 4 hours, in contrast to the NEK11 MT protein showing a half-life of approximately 1 hour in FM6 cells (figure 6A-C). Collectively, we provide evidence that the NEK11 p.Arg374Ter mutation leads to the synthesis of a truncated protein with a very short half-life, suggesting a LOF mutation, supporting a tumour-suppressive role for NEK11 in familial melanoma.

\section{DISCUSSION}

Here, a novel nonsense protein truncating variant (PTV) in NEK11 p.Arg374Ter was identified as a possible familial melanoma predisposition mutation in a Dutch family. The possibility
A
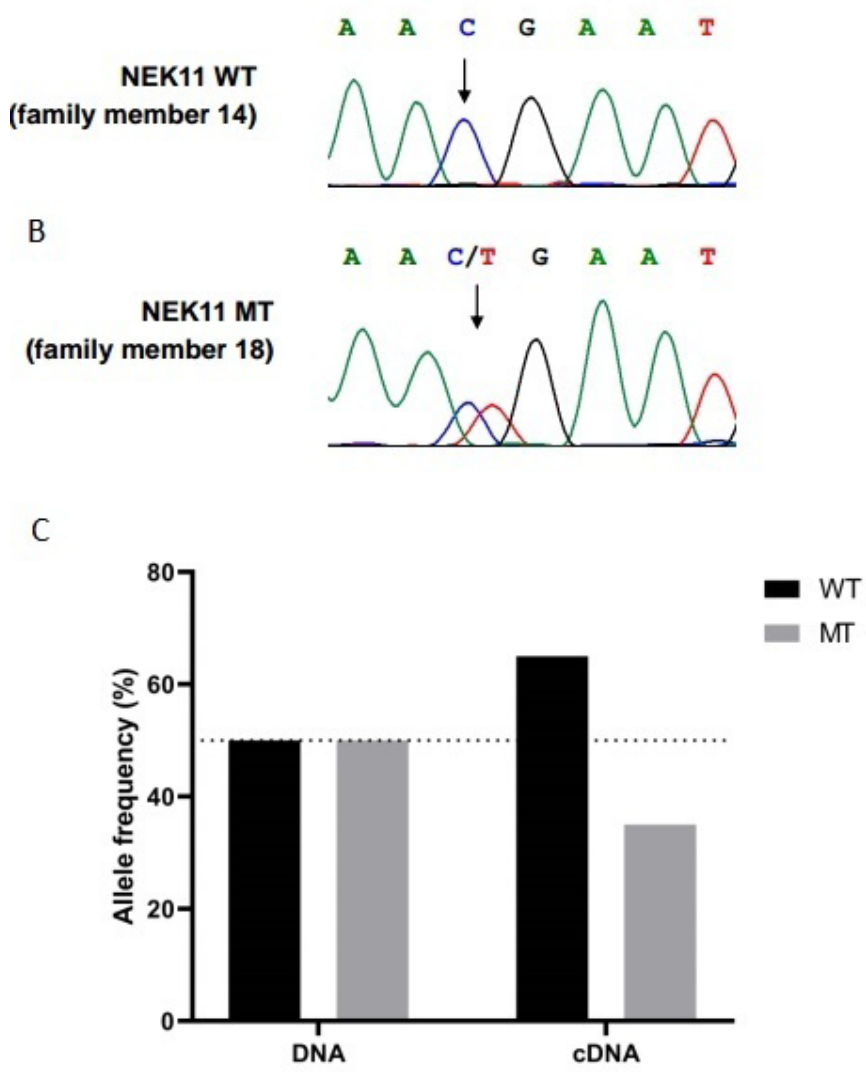

Figure 3 NEK11 wildtype and NEK11 p.Arg374Ter mRNA analysis. Chromatogram showing sequence from $\mathrm{CDNA}$ of $(\mathrm{A})$ healthy family member 14 and (B) a NEK11 p.Arg374Ter carrier (family member 18) Arrows indicate the NEK11 p.Arg374Ter mutation site. (C) Allele frequency of NEK11 WT and NEK11 p.Arg374Ter (MT) detected by ddPCR NEK11 mutation assay using DNA and cDNA from family member 18. WT, wildtype.

of any other potentially damaging variants found by WES in this family to either be causal or contributing to the melanoma-risk of this family was considered. Since not enough scientific evidence was available to support a contributing role, these variants were not investigated further.

NEK11 has been initially characterised as a DNA-damage response kinase with two isoforms, the full-length isoform consisting of 645 residues (NEK11-FL) and the short isoform consisting of 470 residues (NEK11-S). ${ }^{37}$ A regulatory effect during IR-induced G2/M cell-cycle arrest has been described, that is, NEK11 was shown to be involved in phosphorylation of CDC25A triggering its degradation and ultimate blocking of progression into mitosis. ${ }^{27} 3840$ NEK11 has been described to (de) regulate $\mathrm{G} 2 / \mathrm{M}$ cell-cycle arrest in colorectal carcinoma and low expression was observed at late-advanced stages of the disease. ${ }^{27}{ }^{40}$ Furthermore, decreased NEK11 mRNA levels have also been associated with drug resistance in ovarian cancer cells ${ }^{41}$ supporting that NEK11 may prevent metastatic progression in ovarian cancer. Collectively, these results point towards a putative tumour suppressive role of NEK11.

NEK11 expression follows a cell-cycle dependent manner with a peak at $\mathrm{G} 2 / \mathrm{M}$ phase ${ }^{38}$ and mRNA expression is found in the brain, uterus and lungs with moderate expression in melanoma (median expression=6). ${ }^{42}$ No significant difference in expression between benign nevi and melanomas can be observed $;{ }^{34}$ however, cutaneous melanoma patients with higher 
A

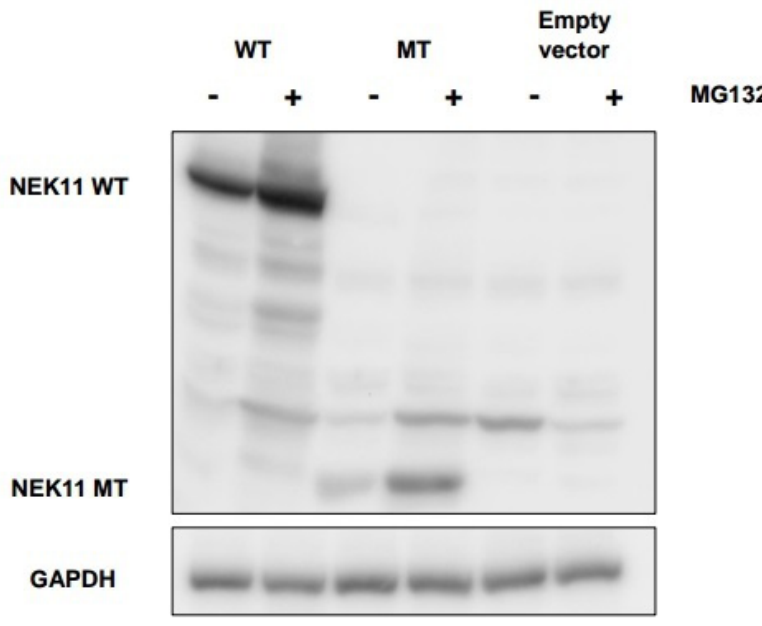

B

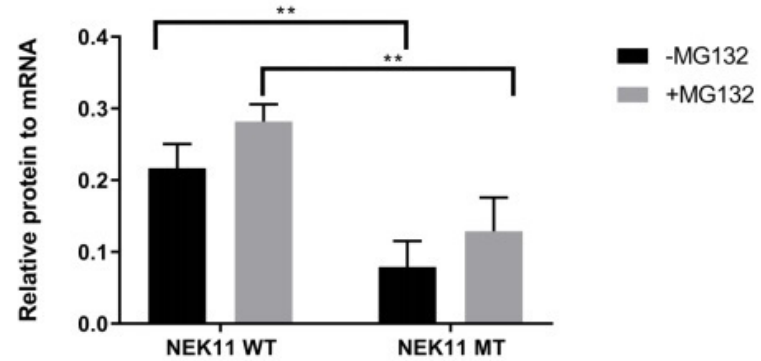

Figure 4 Expression of NEK11 wildtype and p.Arg374Ter in U2OS cells. (A) Lysates of U2OS cells transiently transfected with NEK11 wildtype (WT), NEK11 p.Arg374Ter (MT) and pLV-empty expression plasmids were either untreated or treated with MG132. NEK11 was detected with anti-Flag antibody. GAPDH was determined as a loading control. (B) Expression was calculated relative to GAPDH for each independent experiment and corrected for mRNA expression of NEK11. Data shown represent mean expression from three independent experiments. Error bars represent SD. Statistical significance is shown as ${ }^{*} p<0.05,{ }^{* *} p<0.005$.

NEK11 expression have slightly improved survival, although this association is not statistically significant. ${ }^{35}$ Moreover,NEK11 has been suggested to play a role in the G1/S checkpoint in association with NEK2; however, the exact mechanism remains unknown. ${ }^{39} 44$ Therefore, these data suggest that NEK11 could be regarded an interesting target to validate as a high-penetrance melanoma susceptibility gene.

Genetic analysis confirmed $\mathrm{LOH}$ in the melanoma tissue of a mutation carrier. Expression of NEK11 MT and NEK11 WT allele is detected in lymphocytic RNA indicating that the mutant transcript is not degraded by NMD, confirmed by mRNA expression analysis in transfected U2OS cells.

The oncogenicity of the NEK11 p.Arg374Ter mutation could be caused by two possible scenarios. First, a gain-of-function mutation, as the non-catalytic C-terminal domain was shown to have an autoinhibitory effect on protein function; ${ }^{44}$ thus, loss of this domain could activate the kinase activity. Alternatively, the mutation might lead to the synthesis of a non-functional truncated protein, for example, by loss of coiled-coil domain motifs (online supplementary figure S2a). Here, we provide data strongly suggesting a LOF of the NEK11 p.Arg374Ter mutation. Collectively, our results implicate that the truncated NEK11 protein has a very short half-life, implying that the mutant protein is not significantly expressed in cells and reflects a lossof-function. Since loss of NEK11 abrogates the G2/M cell cycle

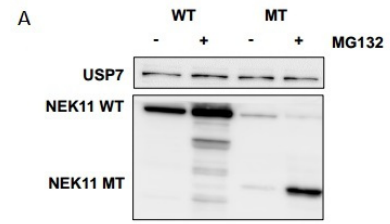

B
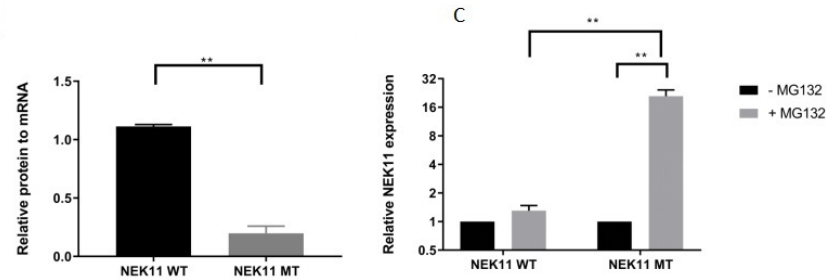

Figure 5 NEK11 protein expression and quantification in stablytransduced FM6 cells. (A) Western blot analysis of cell lysates extracted from stably transduced FM6 cells, either untreated or treated with MG132. NEK11 was detected using anti-Flag antibody. USP7 was detected as a loading control. (B) Protein expression quantifications. Expression was calculated relative to USP7 for each independent experiment and corrected for mRNA expression. (C) Effect of MG132 on NEK11 wildtype (WT) and p.Arg374Ter (MT) expression. NEK11 WT and MT expression was set to 1 and the $\log 10$ relative expression to USP7 is shown. Unpaired t-test was performed for statistical significance. Experiments performed in duplicates. Error bars represent SD. Statistical significance is shown as ${ }^{*} \mathrm{p}<0.05$, ${ }^{* *} p<0.005$. WT, wildtype.

arrest on DNA damaging agents and can induce apoptosis, ${ }^{25}$ it is very well possible that LOF results in genomic instability with the possible selection of cells with increased survival and proliferation, stimulating the acquirement of additional mutations and the development into a tumour.

Unfortunately, our analyses of NEK11 p.Arg374Ter mutation were restricted by the limited availability of relevant (tumour) tissue, as we only had access to melanoma tissue and lymphocytic RNA from one affected family member. Analysis of tumour tissue from more affected family members could strengthen the case for NEK11 as a novel melanoma-susceptibility gene. Moreover, the NEK11 p.Arg374Ter mutation had 14 submissions in
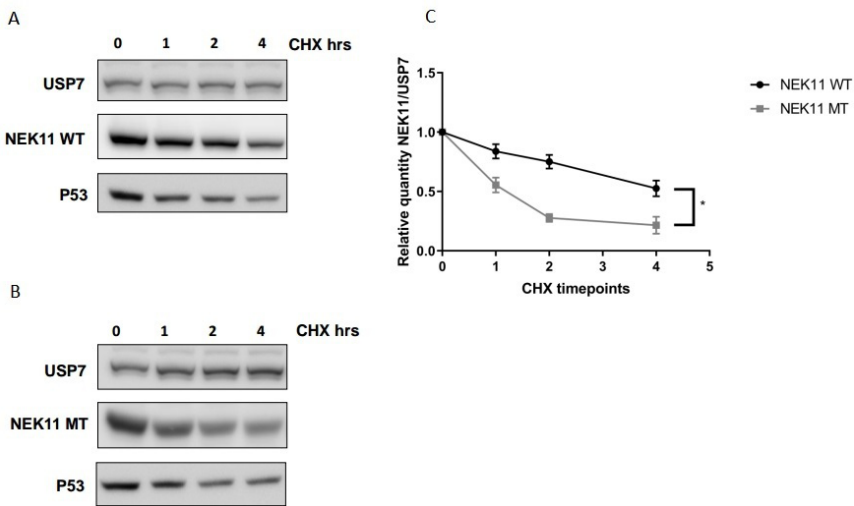

Figure 6 NEK11 protein half-life analysis in FM6 cells using CHX treatments. Time-course $\mathrm{CHX}$ treatments of FM6 cells expressing (A) NEK11 WT) and (B) NEK11 p.Arg374Ter (MT). USP7 was detected as a loading control and P53 as a positive control. (C) Quantification of NEK11 WT and MT corrected for USP7 expression over different time-points of $\mathrm{CHX}$ treatments. Error bars represent SD. Pearson R squared correlation value was 0.82 . Statistical significance is shown as ${ }^{*} p<0.05,{ }^{* *} p<0.005$, ${ }^{* * *} p<0.0005$. CHX, cycloheximide; WT, wildtype. 
dbSNP, although frequency of the alternate allele was extremely low (0-0.00003) and was not found in the Genome of The Netherlands (GoNL) database. ${ }^{3045} 46$ In a recent study, $>300$ 000 UK WES/WGS non-melanoma data sets were analysed for non-synonymous PTVs; ${ }^{47}$ however, no mutations were identified in NEK11, further strengthening NEK11 to be a novel but rare melanoma-susceptibility gene and p.Arg374Ter as a potential pathogenic mutation.

As to why this family is predisposed to develop melanoma and not a different tumour type, we cannot conclude based on data from a single family. The increased risk of only one or a few tumour types is common in monogenic tumour predisposition syndromes. ${ }^{48}$ Furthermore, the absence of any NEK11 mutation in 488 Dutch familial melanoma cases ${ }^{49}$ warrants screening for NEK11 mutations in melanoma families worldwide in order to confirm the importance of NEK11 as a melanoma-susceptibility gene.

\section{Twitter Eirini Christodoulou @IreneChristodou}

Contributors RVD and NG formulated research goals and aims. WES analysis was performed by NKH. Experiments were performed by EC, MVi, AT, MVe. PadV supervised Digital PCR analyses. AJ supervised functional analyses in cell lines. Statistical analysis was performed by EC. Overall progress was supervised by RvD, AJ and NG.

Funding This project has received funding from the European Union's Horizon 2020 research and innovation programme under grant agreement No. 641458. Mijke Visser and Nick Hayward were supported by grant from the Dutch Cancer Society (UL2012-5489) and the National Health and Medical Research Council of Australia, respectively.

Competing interests None declared.

Patient consent for publication Not required.

Provenance and peer review Not commissioned; externally peer reviewed.

Data availability statement All data relevant to the study are included in the article or uploaded as supplementary information.

\section{ORCID iD}

Eirini Christodoulou http://orcid.org/0000-0003-4153-7974

\section{REFERENCES}

1 Schadendorf D, van Akkooi ACJ, Berking C, Griewank KG, Gutzmer R, Hauschild A, Stang A, Roesch A, Ugurel S, Melanoma US. Melanoma. The Lancet 2018:392:971-84

2 Leachman SA, Carucci J, Kohlmann W, Banks KC, Asgari MM, Bergman W, BianchiScarrà G, Brentnall T, Bressac-de Paillerets B, Bruno W, Curiel-Lewandrowski C, de Snoo FA, Debniak T, Demierre M-F, Elder D, Goldstein AM, Grant-Kels J, Halpern AC, Ingvar C, Kefford RF, Lang J, MacKie RM, Mann GJ, Mueller K, Newton-Bishop J, Olsson H, Petersen GM, Puig S, Rigel D, Swetter SM, Tucker MA, Yakobson E, Zitelli JA Tsao $\mathrm{H}$. Selection criteria for genetic assessment of patients with familial melanoma. $J$ Am Acad Dermatol 2009;61:677.e1-677.e14.

3 Potrony M, Badenas C, Aguilera P, Puig-Butille JA, Carrera C, Malvehy J, Puig S. Update in genetic susceptibility in melanoma. Ann Trans/ Med 2015;3.

4 Aoude LG, Wadt KAW, Pritchard AL, Hayward NK. Genetics of familial melanoma: 20 years after CDKN2A. Pigment Cell Melanoma Res 2015:28:148-60.

5 Goldstein AM, Chan M, Harland M, Hayward NK, Demenais F, Bishop DT, Azizi E, Bergman W, Bianchi-Scarra G, Bruno W, Calista D, Albright LAC, Chaudru V, Chompret A, Cuellar F, Elder DE, Ghiorzo P, Gillanders EM, Gruis NA, Hansson J, Hogg D, Holland EA, Kanetsky PA, Kefford RF, Landi MT, Lang J, Leachman SA, MacKie RM, Magnusson V, Mann GJ, Bishop JN, Palmer JM, Puig S, Puig-Butille JA, Stark M, Tsao H, Tucker MA, Whitaker L, Yakobson E, Lund Melanoma Study Group, Melanoma Genetics Consortium (GenoMEL) . Features associated with germline CDKN2A mutations: a GenoMEL study of melanoma-prone families from three continents. J Med Genet 2007:44:99-106.

6 Kamb A, Shattuck-Eidens D, Eeles R, Liu Q, Gruis NA, Ding W, Hussey C, Tran T, Miki Y, Weaver-Feldhaus J, McClure M, Aitken JF, Anderson DE, Bergman W, Frants R, Goldgar DE, Green A, MacLennan R, Martin NG, Meyer LJ, Youl P, Zone JJ, Skolnick $\mathrm{MH}$, Cannon-Albright LA. Analysis of the p16 gene (CDKN2) as a candidate for the chromosome 9p melanoma susceptibility locus. Nat Genet 1994;8:22-6.

7 Hussussian CJ, Struewing JP, Goldstein AM, Higgins PAT, Ally DS, Sheahan MD, Clark WH, Tucker MA, Dracopoli NC. Germline p16 mutations in familial melanoma. Nat Genet 1994;8:15-21.
8 Gruis NA, van der Velden PA, Sandkuijl LA, Prins DE, Weaver-Feldhaus J, Kamb A, Bergman W, Frants RR. Homozygotes for CDKN2 (p16) germline mutation in Dutch familial melanoma kindreds. Nat Genet 1995;10:351-3.

9 Zuo L, Weger J, Yang Q, Goldstein AM, Tucker MA, Walker GJ, Hayward N, Dracopoli NC. Germline mutations in the p16INK4a binding domain of CDK4 in familial melanoma. Nat Genet 1996;12:97-9.

10 Wiesner T, Fried I, Ulz P, Stacher E, Popper H, Murali R, Kutzner H, Lax S, Smolle-Jüttne F, Geigl JB, Speicher MR. Toward an Improved Definition of the Tumor Spectrum Associated With BAP1 Germline Mutations. JCO 2012;30:e337-40.

11 Jensen DE, Proctor M, Marquis ST, Gardner HP, Ha SI, Chodosh LA, Ishov AM, Tommerup N, Vissing H, Sekido Y, Minna J, Borodovsky A, Schultz DC, Wilkinson KD, Maul GG, Barlev N, Berger SL, Prendergast GC, Rauscher FJ. Bap1: a novel ubiquitin hydrolase which binds to the BRCA1 ring finger and enhances BRCA1-mediated cell growth suppression. Oncogene 1998;16:1097-112.

12 Testa JR, Cheung M, Pei J, Below JE, Tan Y, Sementino E, Cox NJ, Dogan AU, Pass HI, Trusa S, Hesdorffer M, Nasu M, Powers A, Rivera Z, Comertpay S, Tanji M, Gaudino G, Yang H, Carbone M. Germline BAP1 mutations predispose to malignant mesothelioma. Nat Genet 2011;43:1022-5.

13 Abdel-Rahman MH, Pilarski R, Cebulla CM, Massengill JB, Christopher BN, Boru G, Hovland P, Davidorf FH. Germline BAP1 mutation predisposes to uveal melanoma, lung adenocarcinoma, meningioma, and other cancers. J Med Genet 2011;48:856-9.

14 Bertolotto C, Lesueur F, Giuliano S, Strub T, de Lichy M, Bille K, Dessen P, d'Hayer $B$, Mohamdi H, Remenieras A, Maubec $E$, de la Fouchardière A, Molinié V, Vabres P, Dalle S, Poulalhon N, Martin-Denavit T, Thomas L, Andry-Benzaquen P, Dupin N, Boitier $F$, Rossi A, Perrot J-L, Labeille B, Robert C, Escudier B, Caron O, Brugières L, Saule S, Gardie B, Gad S, Richard S, Couturier J, Teh BT, Ghiorzo P, Pastorino L, Puig S, Badenas C, Olsson H, Ingvar C, Rouleau E, Lidereau R, Bahadoran $P$, Vielh $\mathrm{P}$, Corda E, Blanché $H$, Zelenika D, Galan P, Aubin F, Bachollet B, Becuwe C, Berthet P, Bignon YJ, Bonadona V, Bonafe J-L, Bonnet-Dupeyron M-N, Cambazard F, Chevrant-Breton J, Coupier I, Dalac S, Demange L, d'Incan M, Dugast C, Faivre $L$, Vincent-Fétita L, Gauthier-Villars M, Gilbert B, Grange F, Grob J-J, Humbert P, Janin $\mathrm{N}$, Joly $\mathrm{P}$, Kerob $\mathrm{D}$, Lasset $\mathrm{C}$, Leroux D, Levang J, Limacher J-M, Livideanu C, Longy M, Lortholary A, Stoppa-Lyonnet D, Mansard S, Mansuy L, Marrou K, Matéus C, Maugard C, Meyer N, Nogues C, Souteyrand P, Venat-Bouvet L, Zattara H, Chaudru V, Lenoir GM, Lathrop M, Davidson I, Avril M-F, Demenais F, Ballotti R, Bressac-de Paillerets B, French Familial Melanoma Study Group. A SUMOylation-defective MITF germline mutation predisposes to melanoma and renal carcinoma. Nature 2011;480:94-8.

15 Yokoyama S, Woods SL, Boyle GM, Aoude LG, MacGregor S, Zismann V, Gartside M, Cust AE, Haq R, Harland M, Taylor JC, Duffy DL, Holohan K, Dutton-Regester K, Palmer JM, Bonazzi V, Stark MS, Symmons J, Law MH, Schmidt C, Lanagan C, O'Connor L, Holland EA, Schmid H, Maskiell JA, Jetann J, Ferguson M, Jenkins MA, Kefford RF, Giles GG, Armstrong BK, Aitken JF, Hopper JL, Whiteman DC, Pharoah PD, Easton DF, Dunning AM, Newton-Bishop JA, Montgomery GW, Martin NG, Mann GJ, Bishop DT, Tsao H, Trent JM, Fisher DE, Hayward NK, Brown KM. A novel recurrent mutation in MITF predisposes to familial and sporadic melanoma. Nature 2011;480:99-103.

16 Horn S, Figl A, Rachakonda PS, Fischer C, Sucker A, Gast A, Kadel S, Moll I, Nagore E, Hemminki K, Schadendorf D, Kumar R. Tert promoter mutations in familial and sporadic melanoma. Science 2013:339:959-61.

17 Robles-Espinoza CD, Harland M, Ramsay AJ, Aoude LG, Quesada V, Ding Z, Pooley KA, Pritchard AL, Tiffen JC, Petljak M, Palmer JM, Symmons J, Johansson P, Stark MS, Gartside MG, Snowden H, Montgomery GW, Martin NG, Liu JZ, Choi J, Makowski M, Brown KM, Dunning AM, Keane TM, López-Otín C, Gruis NA, Hayward NK, Bishop DT, Newton-Bishop JA, Adams DJ. Pot1 loss-of-function variants predispose to familial melanoma. Nat Genet 2014;46:478-81.

18 Aoude LG, Pritchard AL, Robles-Espinoza CD, Wadt K, Harland M, Choi J, Gartside M, Quesada V, Johansson P, Palmer JM, Ramsay AJ, Zhang X, Jones K, Symmons J, Holland EA, Schmid H, Bonazzi V, Woods S, Dutton-Regester K, Stark MS, Snowden H, van Doorn R, Montgomery GW, Martin NG, Keane TM, López-Otín C, Gerdes A-M Olsson H, Ingvar C, Borg Åke, Gruis NA, Trent JM, Jönsson G, Bishop DT, Mann GJ, Newton-Bishop JA, Brown KM, Adams DJ, Hayward NK. Nonsense mutations in the shelterin complex genes ACD and TERF2IP in familial melanoma. J Nat/ Cancer Inst 2015; 107

19 Teerlink CC, Huff C, Stevens J, Yu Y, Holmen SL, Silvis MR, Trombetti K, Zhao H, Grossman D, Farnham JM, Wen J, Facelli JC, Thomas A, Babst M, Florell SR, Meyer L, Zone JJ, Leachman S, Cannon-Albright LA. A nonsynonymous variant in the GOLM1 gene in cutaneous malignant melanoma. J Natl Cancer Inst 2018;110:1380-5.

20 Artomov M, Stratigos AJ, Kim I, Kumar R, Lauss M, Reddy BY, Miao B, Daniela RoblesEspinoza C, Sankar A, Njauw C-N, Shannon K, Gragoudas ES, Marie Lane A, lyer V, Newton-Bishop JA, Timothy Bishop D, Holland EA, Mann GJ, Singh T, Barrett J, Adams DJ, Jönsson G, Daly MJ, Tsao H, Variant R. Rare variant, gene-based association study of hereditary melanoma using whole-exome sequencing. J Nat/ Cancer Inst 2017;109.

21 Aoude LG, Heitzer E, Johansson P, Gartside M, Wadt K, Pritchard AL, Palmer JM, Symmons J, Gerdes A-M, Montgomery GW, Martin NG, Tomlinson I, Kearsey S, Hayward NK. Pole mutations in families predisposed to cutaneous melanoma. Fam Cancer 2015;14:621-8.

22 Read J, Wadt KAW, Hayward NK. Melanoma genetics. J Med Genet 2016;53:1-14. 
23 Visser M, van der Stoep N, Gruis N. Progress report on the major clinical advances in patient-oriented research into familial melanoma (2013-2018). Fam Cancer 2019;18:267-71.

24 Glusman G, Caballero J, Mauldin DE, Hood L, Roach JC. Kaviar: an accessible system for testing SNV novelty. Bioinformatics 2011;27:3216-7.

25 Pritchard AL, Johansson PA, Nathan V, Howlie M, Symmons J, Palmer JM, Hayward NK. Germline mutations in candidate predisposition genes in individuals with cutaneous melanoma and at least two independent additional primary cancers. PLoS One 2018;13:e0194098.

26 Versluis M, de Lange MJ, van Pelt SI, Ruivenkamp CAL, Kroes WGM, Cao J, Jager MJ, Luyten GPM, van der Velden PA. Digital PCR validates $8 q$ dosage as prognostic tool in uveal melanoma. PLoS One 2015;10:e0116371.

27 Sabir SR, Sahota NK, Jones GDD, Fry AM. Loss of Nek11 prevents G2/M arrest and promotes cell death in HCT116 colorectal cancer cells exposed to therapeutic DNA damaging agents. PLoS One 2015;10:e0140975.

28 Carlotti F, Bazuine M, Kekarainen T, Seppen J, Pognonec P, Maassen JA, Hoeben RC. Lentiviral vectors efficiently transduce quiescent mature 3T3-L1 adipocytes. Molecular Therapy 2004;9:209-17.

29 Heijkants RC, Nieveen M, Hart K. C.'t, Teunisse AFAS, Jochemsen AG. Targeting MDMX and $P K C \delta$ to improve current uveal melanoma therapeutic strategies. Oncogenesis 2018:7:33.

30 Lek M, Karczewski KJ, Minikel EV, Samocha KE, Banks E, Fennell T, O’Donnell-Luria AH, Ware JS, Hill AJ, Cummings BB, Tukiainen T, Birnbaum DP, Kosmicki JA, Duncan LE, Estrada K, Zhao F, Zou J, Pierce-Hoffman E, Berghout J, Cooper DN, Deflaux N, DePristo M, Do R, Flannick J, Fromer M, Gauthier L, Goldstein J, Gupta N, Howrigan D, Kiezun A, Kurki MI, Moonshine AL, Natarajan P, Orozco L, Peloso GM, Poplin R, Rivas MA, Ruano-Rubio V, Rose SA, Ruderfer DM, Shakir K, Stenson PD, Stevens C, Thomas BP, Tiao G, Tusie-Luna MT, Weisburd B, Won H-H, Yu D, Altshuler DM, Ardissino D, Boehnke M, Danesh J, Donnelly S, Elosua R, Florez JC, Gabriel SB, Getz G, Glatt SJ, Hultman CM, Kathiresan S, Laakso M, McCarroll S, McCarthy MI, McGovern D, McPherson R, Neale BM, Palotie A, Purcell SM, Saleheen D, Scharf JM, Sklar P, Sullivan PF, Tuomilehto J, Tsuang MT, Watkins HC, Wilson JG, Daly MJ, MacArthur DG, Exome Aggregation C, Exome Aggregation Consortium. Analysis of protein-coding genetic variation in 60,706 humans. Nature 2016;536:285-91.

31 Zerbino DR, Achuthan P, Akanni W, Amode MR, Barrell D, Bhai J, Billis K, Cummins C, Gall A, Girón CG, Gil L, Gordon L, Haggerty L, Haskell E, Hourlier T, Izuogu OG, Janacek SH, Juettemann T, To JK, Laird MR, Lavidas I, Liu Z, Loveland JE, Maurel T, McLaren W, Moore B, Mudge J, Murphy DN, Newman V, Nuhn M, Ogeh D, Ong CK, Parker A, Patricio M, Riat HS, Schuilenburg H, Sheppard D, Sparrow H, Taylor K, Thormann A, Vullo A, Walts B, Zadissa A, Frankish A, Hunt SE, Kostadima M, Langridge N, Martin FJ, Muffato M, Perry E, Ruffier M, Staines DM, Trevanion SJ, Aken BL, Cunningham F, Yates A, Flicek P. Ensembl 2018. Nucleic Acids Res 2018;46:D754-61.

32 Meirelles GV, Perez AM, de Souza EE, Basei FL, Papa PF, Melo Hanchuk TD, Cardoso VB, Kobarg J. "Stop Ne (c)king around": How interactomics contributes to functionally characterize Nek family kinases. World J Biol Chem 2014;5:141-60.

33 Tate JG, Bamford S, Jubb HC, Sondka Z, Beare DM, Bindal N, Boutselakis H, Cole CG, Creatore C, Dawson E, Fish P, Harsha B, Hathaway C, Jupe SC, Kok CY, Noble K, Ponting L, Ramshaw CC, Rye CE, Speedy HE, Stefancsik R, Thompson SL, Wang S, Ward S, Campbell PJ, Forbes SA. Cosmic: the Catalogue of somatic mutations in cancer. Nucleic Acids Res 2019;47:D941-7.
34 Rhodes DR, Yu J, Shanker K, Deshpande N, Varambally R, Ghosh D, Barrette T, Pander A, Chinnaiyan AM. ONCOMINE: a cancer microarray database and integrated datamining platform. Neoplasia 2004;6:1-6

35 Chandrashekar DS, Bashel B, Balasubramanya SAH, Creighton CJ, Ponce-Rodriguez I, Chakravarthi BVSK, Varambally S. UALCAN: a portal for facilitating tumor subgroup gene expression and survival analyses. Neoplasia 2017;19:649-58.

36 Hindson CM, Chevillet JR, Briggs HA, Gallichotte EN, Ruf IK, Hindson BJ, Vessella RL, Tewari M. Absolute quantification by droplet digital PCR versus analog real-time PCR. Nat Methods 2013;10:1003-5.

37 Noguchi K, Fukazawa H, Murakami Y, Uehara Y. Nek11, a new member of the NIMA family of kinases, involved in DNA replication and genotoxic stress responses. J. Biol. Chem. 2002;277:39655-65.

38 Melixetian M, Klein DK, Sørensen CS, Helin K. Nek11 regulates Cdc25A degradation and the IR-induced G2/M checkpoint. Nat Cell Biol 2009;11:1247-53.

39 Fry AM, O'Regan L, Sabir SR, Bayliss R. Cell cycle regulation by the NEK family of protein kinases. J Cell Sci 2012;125:4423-33.

40 Sørensen CS, Melixetian M, Klein DK, Helin K. NEK11-Linking Chk1 and Cdc25A in DNA damage checkpoint signaling. Cell Cycle 2010;9:450-5.

41 LIU XIA, Gao Y, Lu YI, Zhang J, Li LI, Yin F. Downregulation of Nek11 is associated with drug resistance in ovarian cancer. Int J Oncol 2014;45:1266-74.

42 Cerami E, Gao J, Dogrusoz U, Gross BE, Sumer SO, Aksoy BA, Jacobsen A, Byrne CJ, Heuer ML, Larsson E, Antipin Y, Reva B, Goldberg AP, Sander C, Schultz N. The cBio cancer genomics portal: an open platform for exploring multidimensional cancer genomics data: Figure 1. Cancer Discov 2012;2:401-4.

43 Gao J, Aksoy BA, Dogrusoz U, Dresdner G, Gross B, Sumer SO, Sun Y, Jacobsen A, Sinha R, Larsson E, Cerami E, Sander C, Schultz N. Integrative analysis of complex cancer genomics and clinical profiles using the cBioPortal. Sci Signal 2013;6:pl1.

44 Noguchi K, Fukazawa H, Murakami Y, Uehara Y. Nucleolar Nek1, Is a Novel Target of Nek2A in G, /S-arrested Cells. J. Biol. Chem. 2004;279:32716-27.

45 Sherry ST, Ward MH, Kholodov M, Baker J, Phan L, Smigielski EM, Sirotkin K. dbSNP: the NCBI database of genetic variation. Nucleic Acids Res 2001;29:308-11.

46 Boomsma DI, Wijmenga C, Slagboom EP, Swertz MA, Karssen LC, Abdellaoui A, Ye K, Guryev V, Vermaat M, van Dijk F, Francioli LC, Hottenga JJ, Laros JFJ, Li Q, Li Y, Cao H, Chen R, Du Y, Li N, Cao S, van Setten J, Menelaou A, Pulit SL, Hehir-Kwa JY, Beekman M, Elbers CC, Byelas H, de Craen AJM, Deelen P, Dijkstra M, den Dunnen JT, de Knijff P, Houwing-Duistermaat J, Koval V, Estrada K, Hofman A, Kanterakis A, Enckevort Dvan, Mai H, Kattenberg M, van Leeuwen EM, Neerincx PBT, Oostra B, Rivadeneira F, Suchiman EHD, Uitterlinden AG, Willemsen G, Wolffenbuttel BH, Wang J, de Bakker PIW, van Ommen G-J, van Duijn CM. The genome of the Netherlands: design, and project goals. Eur J Hum Genet 2014;22:221-7.

47 DeBoever C, Tanigawa Y, Lindholm ME, Mclnnes G, Lavertu A, Ingelsson E, Chang C, Ashley EA, Bustamante CD, Daly MJ, Rivas MA. Medical relevance of proteintruncating variants across 337,205 individuals in the UK Biobank study. Nat Commun 2018;9:1612.

48 Rahman N. Realizing the promise of cancer predisposition genes. Nature 2014;505:302-8.

49 Potjer TP, Bollen S, Grimbergen A, van Doorn R, Gruis NA, van Asperen CJ, Hes FJ, van der Stoep N. Multi-Gene panel sequencing of established and candidate melanoma susceptibility genes in a large cohort of Dutch non-CDKN2A/CDK4 melanoma families. Int J Cancer 2018. 